\title{
Imposing legality: hegemony and resistance under the EU Forest Law Enforcement, Governance, and Trade (FLEGT) initiative
}

\author{
Rodd Myers a,b,e 1 \\ Rebecca Rutt b,c \\ Constance McDermott ${ }^{\mathrm{d}}$ \\ Ahmad Maryudi a,e \\ Emmanuel Acheampong ${ }^{\mathrm{f}}$ \\ Marisa Camargo ${ }^{g}$ \\ Hoàng Cầm ${ }^{\mathrm{h}}$

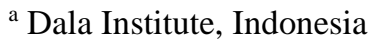 \\ ${ }^{\mathrm{b}}$ University of East Anglia, UK \\ c University of Copenhagen, Denmark \\ ${ }^{\mathrm{d}}$ University of Oxford, UK \\ e Gadjah Mada University, Indonesia \\ ${ }^{\mathrm{f}}$ Kwame Nkrumah University of Science and Technology, Ghana \\ g University of Helsinki, Finland \\ ${ }^{\text {h }}$ Vietnam Academy of Social Sciences, Vietnam
}

\begin{abstract}
Timber legality trade restrictions and verification are a bundle of contemporary mechanisms triggered by global concerns about forest degradation and deforestation. The European Union Forest Law Enforcement, Governance and Trade initiative is a significant effort to not only screen out illegal timber and wood products from the EU, but also support trading partner countries to improve their legality definitions and verification processes. But by using bilateral agreements (Voluntary Partnership Agreements) as a key mechanism, the EU legitimizes trade partner nation-states as the authority to decide what is legal. We engage in a theoretical debate about the complexities of the meaning of legality, and then analyze empirical data collected from interviews in Ghana, Indonesia, Vietnam and Europe with policy, civil society and industry actors to understand how different actors understand legality. We find hegemonic notions of Westphalian statehood at the core of 'global' notions of legality and often contrast with local understandings of legality. Non-state actors understand these

${ }^{1}$ Dr. Rodd Myers, Dala Institute, Jakarta, Indonesia; Global Environmental Justice Group, School of International Development University of East Anglia, UK; Sebijak Institute, Faculty of Forestry, Universitas Gadjah Mada, Indonesia. Email: r.myers "at" dala.institute. Dr. Rebecca Rutt, Department of Food and Resource Economics, University of Copenhagen, Denmark. Email: rlr "at" ifro.ku.dk and formerly Global Environmental Justice Group, School of International Development University of East Anglia, UK. Dr. Constance McDermott, Environmental Change Institute, University of Oxford, UK. Email: constance.mcdermott "at" ouce.ox.ac.uk. Prof. Ahmad Maryudi, Sebijak Institute, Faculty of Forestry, Universitas Gadjah Mada, Indonesia; Dala Institute, Indonesia. Email: ahmad_maryudi "at" ugm.ac.id. Dr. Emmanuel Acheampong, Department of Silviculture and Forest Management, Kwame Nkrumah University of Science and Technology, Ghana. Email: ekachie "at" yahoo.com. Marisa Camargo, Department of Forest Sciences the Viikki Tropical Resources Institute (VITRI), University of Helsinki, Finland. Email: marisa.camargo "at" gmail.com. Dr. Hoàng Cầm, Vietnam Academy of Social Sciences, Vietnam. Email: hoangcamvn "at" gmail.com. Acknowledgements: This article is an output of Supranational Forest Governance in an Era of Globalising Wood Production and Justice Politics (ProdJus), supported by Riksbankens Jubileumsfond in collaboration with the Wellcome Trust and VolkswagenStiftung through the Europe and Global Challenges initiative, grant number GC15-1236:1. We appreciate the foundational leadership of Professor Thomas Sikor to develop our research design and inspire our approaches and perspectives. Thank you to referees who provided sage advice and greatly improved the paper.
\end{abstract}


hegemonic notions of legality as imposed upon them and part of a colonial legacy. Further, notions of legality that fail to conform with hegemonic understandings are readily framed by nation-states as immoral or criminal. We emphasize the importance of understanding these framings to elucidate the embedded assumptions about what comprises legality within assemblages of global actors.

Key words: FLEGT, timber legality, hegemony, power, globalization

\section{Résumé}

Les restrictions et la vérification du commerce de la légalité du bois sont un ensemble de mécanismes contemporains déclenchés par les préoccupations mondiales concernant la dégradation des forêts et la déforestation. L'initiative de l'Union Européenne «Application des lois forestières, gouvernance et commerce» est un effort important non seulement pour éliminer le bois et les produits du bois illégaux de l'UE, mais aussi pour aider les pays partenaires commerciaux à améliorer leurs définitions de la légalité et leurs processus de vérification. Mais en utilisant des accords bilatéraux (accords de partenariat volontaires) comme mécanisme clé, l'UE légitime les États-nations partenaires commerciaux en tant qu'autorité pour décider de ce qui est légal. Nous nous engageons dans un débat théorique sur la complexité du sens de la légalité, puis analysons les données empiriques collectées lors d'entretiens au Ghana, en Indonésie, au Vietnam et en Europe avec des acteurs politiques, de la société civile et de l'industrie pour comprendre comment les différents acteurs comprennent la légalité. Nous trouvons les notions hégémoniques de l'État westphalien au cœur des notions «mondiales» de légalité et contrastent souvent avec les interprétations locales de la légalité. Les acteurs non étatiques comprennent ces notions hégémoniques de légalité qui leur sont imposées et font partie d'un héritage colonial. De plus, les notions de légalité qui ne sont pas conformes aux interprétations hégémoniques sont facilement qualifiées d'immorales ou criminelles par les États-nations. Nous soulignons l'importance de comprendre ces cadrages pour élucider les hypothèses intégrées sur ce qui comprend la légalité au sein des assemblages d'acteurs mondiaux.

Mots-clés: FLEGT, légalité du bois, hégémonie, pouvoir, mondialisation

\section{Resumen}

Las restricciones y la verificación de la legalidad de la madera para el comercio, son un conjunto de mecanismos contemporáneos que se han disparado por la preocupación global por la degradación de los bosques y la deforestación. La iniciativa de la Unión Europea sobre Aplicación de las Leyes, Gobernanza y Comercio Forestales, es un importante esfuerzo no solamente para eliminar la madera y los productos forestales ilegales de la Unión Europea, sino también para respaldar a los países socios comerciales para que optimicen sus procesos de definición y verificación de legalidad. Sin embargo, al tener acuerdos bilaterales (acuerdos voluntarios de asociación) como mecanismos, la Unión Europea legitima a las naciones-estados que son socios comerciales como una autoridad para decidir lo que es legal. Iniciamos un debate teórico sobre las complejidades del significado de legalidad, para luego analizar datos empíricos recolectados de entrevistas con actores de la sociedad civil y la industria en Ghana, Indonesia, Vietnam y Europa para conocer cómo cada uno entiende el concepto de legalidad. Ahí nos encontramos nociones hegemónicas sobre categorías de estado de Westfalia como base de las nociones "globales"de legalidad y un frecuente contraste con las interpretaciones locales de ese mismo concepto. Los actores ajenos al estado entienden estas nociones hegemónicas de legalidad como impuestas y como parte de un legado colonial. Adicionalmente, las nociones de legalidad que fallan en ajustarse a la percepción hegemónica, están rápidamente incriminados por los estado-nación por considerarse inmorales o criminales. Nosotros enfatizamos la importancia de entender estos entramados para explicar los supuestos involucrados sobre lo que comprende la legalidad dentro de los ensamblajes de actores globales.

Palabras clave: FLEGT, legalidad de la madera, hegemonía, poder, globalización

\section{Introduction}

Timber legality trade restrictions and verification are a bundle of contemporary mechanisms implemented in response to global concerns regarding forest degradation and deforestation. It has been projected that forest degradation and deforestation will affect the lives and livelihoods of approximately two billion people for the next 25 years (Humphreys 2006), threaten global biodiversity, and significantly contribute to carbon emissions. Since timber production is a significant driver of forest loss, and illegally traded 
timber products account for between 15 and 30 percent of total global timber markets (Interpol 2017), global actors have adopted tackling illegal timber trade as a key strategy to address forest loss (see McDermott 2014).

The European Union (EU) has played a leading role in international attempts to combat illegal logging, beginning with its 2003 Forest Law Enforcement Governance and Trade (FLEGT) Action Plan aimed at eradicating the placing of illegal timber on EU markets. Two central mechanisms that emerged from the Action Plan are Voluntary Partnership Agreements (VPAs) and the EU Timber Regulation (EUTR) (European Parliament and Council 2010).

VPAs, the first major FLEGT mechanism to be adopted, involve negotiated bilateral agreements between the EU and timber producing countries. These agreements define legal timber in the country of origin and establish a timber legality assurance system (TLAS) to verify and certify legality (EU FLEGT Facility 2009). Seven countries - Ghana, Indonesia, Cameroon, Republic of Congo, Central African Republic, Liberia, and Vietnam have entered into VPAs with the EU (EU FLEGT Facility 2019).

The EUTR, the second FLEGT mechanism, was adopted in 2010 and entered into application in 2013. The EUTR is a legal act that addresses the market demand driving the illegal trade of timber with the EU. The regulation has the following three primary objectives:

1. to prevent the placement of illegal timber and products derived from such timber on the internal EU market;

2. to require operators who place timber products on the EU market for the first time to exercise 'due diligence'; and

3. to require traders of timber and timber products that have already been placed on the market to maintain records of their suppliers and customers.

It defines illegal timber as the wood harvested in a way that breaches the laws or regulations of the country of harvest (European Parliament and Council 2010, sec. 2f). It does not directly create new legal requirements but mandates that operators prove that they have complied with the rules of the country of harvest.

The EUTR covers 90\% of EU imports of timber and wood products (Weimar, Janzen and Dieter 2015). Together, the VPAs and EUTR are expected to bring the substantial authority of supranational and state actors to bear on illegal timber operators in the targeted countries. Legislation similar to the EUTR has been enacted in other countries, including the US Lacey Act Amendment (2006), Japanese Goho-Wood legislation, and Australian Illegal Logging Prohibition Act (Masiero, Pettenella and Cerutti 2015; Maryudi 2015).

A growing body of literature has examined governance innovations within FLEGT (Overdevest and Zeitlin 2018; Hansen, Rutt and Acheampong 2018; Overdevest and Zeitlin 2018; Rutt et al. 2018), implications for markets and traders (Masiero, Pettenella and Cerutti 2015; Maryudi and Myers 2018), and links to sustainability (Lesniewska and McDermott 2014). In this article, we specifically investigate some facets of FLEGT that have not been examined thoroughly in the literature. Particularly, we examine the inherent assumptions, and their hegemonic underpinnings, that ultimately influence who (and what) stands to benefit from the FLEGT initiative. In other words, whose logics inform FLEGT and what does that mean for different actors?

We analyze the ways in which FLEGT (specifically the EUTR and VPAs) imposes particular logics on the definition of timber legality and the actors authorized to define it. In particular, we compare and contrast the key framings of (a) supranational and local authority over forest resources, (b) the legitimacy of the role of the nation-state in authorizing the legal and illegal, and (c) what this means for the governance of forests and forest resources.

Framings of legality matter at the global and local scales, as embedded in the EU FLEGT VPAs and EUTR. Drawing from interview data from EU FLEGT-affiliated organizations and the timber industry, as well as from respondents belonging to multiple stakeholder groups in Europe and the VPA countries Ghana and Indonesia, we determine the extent to which the EU FLEGT represents (1) an expression of particular (normative) values, namely ideas about governance and legality rooted in Westphalian, colonial, and state- 
making logics and (2) an exercise of power, as (hegemonic) notions are imposed on actors in various ways and at many levels of production, including through the framing of alternative ideas (to state hegemony and the status quo) about timber access and management as 'evil', thereby compelling actors to fall in line with global/EU notions. Specifically, we initially explore whose legality these policies account for in order to understand how different timber actors' interests are reflected or not in nation-state levels of timber legality definitions and at 'global' levels. We subsequently interrogate the ways in which non-conformity with nationstate definitions of timber legality are understood by different actors, including the ways in which contrasting perspectives are framed by hegemonic powers. We further discuss these results by considering the overarching frames of authority, legitimacy, and governance. The next sections present our theoretical framing, followed by our methods, results, a discussion, and our conclusions.

\section{Theoretical framing: 'Westphalian' values, legality, and hegemonic norms of global governance}

\section{Global hegemonic governance, Westphalian values, and FLEGT}

In the late 1990s, deforestation and forest degradation were reframed at the global level to emphasize the need for better governance and particularly legality, rather than environmental sustainability (McDermott 2014). While environmental sustainability is still espoused as a target, its meanings are considered too diverse by implementers and policymakers and its definitions too obscure compared with legality, which is ostensibly understood as something more concrete that would lead to sustainability. At the same time, the shift to focusing on legality eschewed a range of environmental and social conflicts that mired efforts toward increasing sustainability (ibid.). In order to maintain the focus of this article, we do not delve deeply into what sustainability is or isn't in the context of forestry, but we suggest that the idea of legality was considered by policy-makers to be a more achievable building block on the way to sustainability than dealing with the complexities of sustainability directly. There remain several questions about the extent to which illegal forestry is counterproductive to sustainability objectives. For instance, 'illegal' chainsaw millers in Ghana contribute significantly to local livelihoods, and in ways that may be considered either currently or potentially sustainable (Lescuyer, Cerutti and Robiglio 2013; Marfo 2009).

Legality can be defined as that which follows the statutes of a particular jurisdiction (Black 1990). It is the property of being law, thus, encompassing "... rules, organizations, officials, texts, concepts, judgements, and so on" (Shapiro 2011: 7). The terms 'law' and 'legality' are typically associated with the rules established by the nation-state, perhaps explaining why this reframing toward legality attracted substantial buy-in from governments in the 'global South'. McDermott (2014: 15) notes, "Unlike the promotion of [sustainable forest management], the idea of tackling illegality won the support of governments [...] For governments better law enforcement would build state authority and legitimacy and facilitate taxation." The foregrounding of nationstate sovereignty within the FLEGT initiative also appealed to European NGOs and Member States, which were familiar with the critiques and challenges of 'top-down' development interventions.

The EU ostensible turn away from top-down approaches by placing itself and its timber-trading partners together to negotiate agreements, and by allowing timber product exporting countries to define legality as sovereign states. However, the EU's FLEGT activities might also be viewed as representative of a global hegemonic order at a deeper level, bearing specific notions and practices of legality and governance rooted in Westphalian ideas of sovereignty. Signed in 1648, the Peace of Westphalia ended decades of war in Europe and established the modern state system based on fixed territorial boundaries. The peace treaty also emphasized that citizens of a country were subject primarily to the laws of their particular governments, based on the understanding that a state is sovereign to rule as it sees fit. The EU - while post-Westphalian as a supranational entity (Caporaso 1996) - is still deeply rooted in the logic of nation-states as supreme entities, hence its buyin to the turn toward legality as essential within global conservation and development initiatives.

Westphalian notions of statehood and sovereignty "rely on such a one-dimensional view of the role of norms and such a very thin notion of the legal order that it becomes impossible to make sense of the tremendous changes that have indeed taken place, above all in the period since 1945" (Hurrell 2002, xvii in a forward to 
Bull). Bull's work is criticized for being restricted to Westphalian state-making, which applies differently outside of Europe (Keene 2002). However, his analysis of the Westphalian state remains accurate. Although the principles of the Peace of Westphalia sought to protect nation-states from gaining hegemonic powers over others (Watson 1992), the notion of nation-statehood is itself hegemonic (Scott 2009).

While we hypothesize that FLEGT is a hegemonic force of natural resource governance, we do not mean to suggest that it is an explicit attempt at maintaining or regaining European control over global natural resources, which is a key tenet of the hegemonic stability theory and a primary driver of colonial expansion (Keohane 1984). Rather, we adopt a Gramscian understanding of hegemony. As Eagleton describes, "Gramsci normally uses the word hegemony to mean the ways in which a governing power wins consent to its rule from those it subjugates" (1991: 112). Hegemony implies a certain degree of subjugation and domination. Gramsci focused on the use of 'cultural institutions' to explain how the state and ruling class held on to power in societies; he used the term "cultural hegemony" with reference to this while emphasizing capitalist societies. Cultural hegemony refers to the way in which the values, beliefs, and perceptions about the world by select (often powerful) groups become normalized or turn into universal norms. From this perspective, we explore whether or not hegemonic approaches to forest governance are "the enemy of equitable governance in situations with diverse interest groups and multiple value systems" (Dawson, Coolsaet and Martin 2018: 34).

As Dingwerth (2008) asserts, most considerations of international and global governance arrangements are shaped by dominant global actors who tend to belong to the most economically powerful countries (see also Duffy 2013). The EU is positioned to impose its notions of governance and legality first because of its considerable power to influence production as a timber product consumer, and second because of its history as a colonial rule-setter, which will be discussed later. Keohane asserts that "The bigger one's own market, and the greater the government's discretion in opening it up or closing it off, the greater one's potential economic power" (1984: 33, see also Cashore, Auld and Newsom 2004). Several examples from the literature can be picked to highlight international law impacting domestic policies (see Slaughter and Burke-White 2006; Bernstein and Cashore 2012).

The hegemonic underpinnings of FLEGT are rooted in a deeper hegemonic notion of forest resource management stemming from colonial rule. This notion predominantly prioritized technocratic approaches for maximizing income generating products while reinforcing centralized rule. The "ideologies and interests represented by scientific forestry, the League of Nations Mandate, indirect rule, and the general process of peasantization intersected in complex and contradictory ways" to restructure forest rights in many countries (Neumann 1997: 46). The same scientific policies, espoused by German expert foresters, remain the cornerstone of forest management and policy today (Peluso 1992). A plethora of examples from the literature reveals the enduring legacy of colonial forest management policies on modern forest governance and law (see Becker 2001; Peluso 1992; Diaw 2005; Wainwright and Zempel 2017; Abrams et al. 2018). Hansen and Lund (2017) describe how technical 'imperial forestry' was introduced in Ghana under British rule in the early 20th century but was never completely implemented in practice due to economic, biophysical, and other challenges and served primarily to legitimate centralized control; a condition that persists today. In Ghana and Indonesia, for example, the legal framework for forest harvest is predominantly tailored around government timber concessions designed to facilitate the extraction of high value timber for export. Meanwhile the growing domestic markets in both countries, which consume the majority of timber products, are dominated by 'informal' trade, for which no viable regulatory framework has yet been established (McDermott, Hirons and Setyowati 2019). These ideas of governance through export-oriented forest concessions, shaped by global actors, are steeped in the logics of historical empire building.

\section{Globalization of governance}

Globalization, as it exists today, employs concepts of international society (or international networks, such as the United Nations, World Bank and G7) and relies on nation-states to gain and maintain legitimacy (Bull and Watson 1984). Nation-states, subsequently, are legitimized by international societies recognizing their authorities. Within these mutually legitimizing networks, there are countless other legitimizing relations both within diverse state institutions and among international societies (see Sikor and Lund 2009 for more on 
mutual legitimation and institutional pluralism typical of post-colonial societies). Institutional societies impact nation-state laws through hegemonic and counter-hegemonic notions and often challenge the democratic control of legislation (K. von Benda-Beckmann 2002; Bull 1977). For example, a significant section of international law is rooted in historically Eurocentric philosophical and legal underpinnings and fails to account for alternative models (Rajagopal 2003). International environmental regimes lean towards neoliberal notions of justice and equity (Okereke 2008) and some authors suggest that the EU and its FLEGT initiative are no exception (see Humphreys 2006). However, the engagement of nation-states with international societies can also erode nation-state sovereignty (Krasner 2001). Contemporary globalization has "challenged the effectiveness of state control" since sovereign states are increasingly becoming intertwined with one another (Krasner 1999: 34). Therefore, complex relationships persist among nation-states and international societies of global actors.

A predominant part of the history of forests has been one of empire building (Grove 1996; Peluso 1992; Vandergeest and Peluso 2006). Some of the most historically prolific times for the globalization of law, and therefore legality, were eras of European colonial expansion (K. von Benda-Beckmann 2002). Colonization was an integral building block of modern extractivist globalization (Milanovic 2003; Quijano 2000; Wainwright and Zempel 2017). However, the 'imperialist project' persists in the legal imperialism championed by proponents of Western moralities (Nader 2009) and reinforces, if not creates, power imbalances (Chomba et al. 2016).

The process of globalization exists within a complicated set of legal constellations established by states. Nation-state laws are often affected by global notions and implementations of legality, resulting in legal pluralism at the highest levels of state (K. von Benda-Beckmann 2002). Global governance, which was initially understood as a radical approach to an outdated economic order, has been increasingly criticized as globalizing hegemonic interests in the service of neoliberal agendas (Overbeek et al. 2010).

\section{Legal pluralism}

Different countries have adopted different legal systems and elected different sources of laws. Each legal system has "concepts through which its rules are expressed; categories within which they are organized; and the legal rule itself in each of them is expressed in a particular way" (David and Brierley 1978). There are basically three primary legal systems adopted by nation-states - the Romano-Greco legal family, socialist law, and common law. However, there are hundreds of thousands of local legal systems that are incorporated in contemporary nation-state legal systems to varying extents. In Indonesia, for example, the nation-state legal system belongs to the Romano-Greco family but is combined with elements of Islamic and - to a limited extent - customary laws; this makes it a complex mixed system that often refers to an ambiguous hierarchy of laws to deal with conflicting provisions. McDermott (2019: 13) describes contemporary international forest governance as multi-scalar, involving "diverse actors at different scales pursuing often conflicting objectives." Acknowledging the ambiguity of the term 'legality' and the complexity of legal systems in some countries, some recognize that laws, regulations and those who claim the authority to define them are highly contestable and subject to change and interpretation (F. von Benda-Beckmann, von Benda-Beckmann, and Griffiths 2012; Maryudi and Sahide 2017; Marks 1992). Embracing multiple legalities may or may not mean loss of power for nation states. Djelic and Sahlin-Andersson (2006: 337), for example, demonstrate that the rise of transnational governance does not mean the decline of state regulation, but that "state regulators are increasingly embedded in and interplay with many other regulatory actors."

While the EU develops policies at the national and supranational levels to address illegal logging, the effects are felt at local levels among people who depend on forests and forest products for their livelihoods (Mwangi and Wardell 2012) and along the commodity chain (Maryudi and Myers 2018). This amalgam of global, national, and local actors results in conflated understandings of the term 'legal timber' as a globalized commodity. Placing the responsibility to prove legality on actors within the global production network does not automatically result in an increased ability to benefit from the sale of timber or wood products (see Maryudi and Myers 2018; and Arora-Jonsson et al. 2016 for a discussion of how responsibilities fail to imbue rights). 
Current framings of the problems of illegality in the forestry sector allot specific roles, responsibilities, and authorities to certain actors and create openings for new interventions. By considering illegal logging as a global problem, global actors are better equipped to address it. The level of attention and resources that global actors can provide may come across as appropriate or even imperative, given the scale of the problem. This perspective legitimizes the oligarchy of 'global' actors such as the EU and other environmental and development institutions from the global North which tend to command the most wealth and 'scientific expertise.' However, in the pursuit of resolving global problems, global actors wield enormous power in (re)shaping or reinforcing institutions in the countries of implementation (Ribot, Chhatre and Lankinad 2008). In the pursuit of legality, 'global' actors propose particular assumptions regarding what the term 'legal' means, including the context and the actors who can define it.

The hegemonic Westphalian notions of legality reinforced by morality coexist with other legalities held by a range of actors. The prevalence of multiple conceptualizations of legality among nation-states is easily understood since each nation-state has an assumed sovereign right to determine its law. Within nation-states, understandings of legality are more elusive. Different branches of government may have different understandings of legality and judicial systems. Constitutional courts, especially, routinely support challenges to the implementation of laws that contradict the constitution (see Myers et al. 2017 as a contemporary example). We use the concept of legal pluralism. Legal pluralism is connected to multiple sets of laws that are applicable to a specific phenomenon or place and that emerged to the forefront in times of colonial expansion; it also relates to the application of international, supranational, religious, customary, and local law (K. von Benda-Beckmann 2002). Legal pluralism means there are

...different actors who are engaged in contestations over who has the power and authority to generate law and construct its meaning. This is especially pertinent in plural legal constellations where there may be contestation over what is the 'correct' law in particular contexts... the power struggles in which they are engaged often reflect asymmetrical power relations among parties and among legal orders. This affects the ways in which law's legitimacy is constituted and reconfigured through social processes that frame both its continuity and transformation over time (F. von Benda-Beckmann, von Benda-Beckmann and Griffiths 2012: 3).

These power struggles often feature customary community law pitted against much more powerful nation-state laws (Randeria 2003) or national laws against more localized forms of state governance (Ribot, Agrawal and Larson 2006) or sovereign states against international (nonbinding) standards, if not law. In the case of the latter, international standards and policies may influence nation-state policies (Cashore and Stone 2012) or vice versa (Vogel 1995).

Globalized ideas of development result in project law, comprising a specific kind of legal plurality in which global actors have a strong influence on domestic policy (Weilenmann 2009). By extension, notions of environmentalism and legality among influential transnational actors have a similar influence on domestic policy (Cashore et al. 2016; Humphreys 2004). Weilenmann (2009: 39) states that,

[o]n the one hand, project law has a homogenizing impact on social change because it structures the development political consulting process through norms that are thought to be applicable worldwide... On the other hand, project law also contains behavioral demands on the local population; it offers project-dependent provisions of new structures for decision making or regulations for the allocation of new resources.

Projects, including FLEGT, contain specific predispositions and assumptions regarding the behavior that they seek to modify. When such projects are championed by powerful actors, they can have a significant influence on nation-state law, determining who engages in undesirable activities and who become criminals. FLEGT can, therefore, influence both the content and the practice of national law. This is possible despite its stated design to influence governance while leaving laws and their implementation to sovereign states (see 
Commission of European Communities 2003). Both the national laws and the EU laws are predicated on a particular notion of morality, which we explore next.

\section{Morality and legality}

Hegemonic notions of legality are reinforced by morality. Legality encompasses much more than the rules set by authorities; it is the canonization of the moral codes existing within and shaped by social and cultural contexts (Ribot 1999). As the 33rd President of the United States proclaimed in 1950, "the fundamental basis of this nation's laws was given to Moses on the Mount...If we don't have a proper fundamental moral background, we will finally end up with a totalitarian government which does not believe in rights for anybody except the state!" (Truman 1950 in Federer 2004: 292). Establishing a legal system is also an attempt to legitimize the moral positions of those who have the authority to influence it. Von Benda-Beckmann et al. (2012: 7) explore this in it the context of transnational politics by stating,

Hegemonic states seek to enforce central Western legal concepts and values upon states that seem to lack these, while at the same time legitimating the unilateral and often illegal use of violence by reference to a higher moral order, thereby undermining the same legal values they seek to impose upon others. In doing so, they pitch an idealistic view of Western law and democracy against a stereotyped negative view of states that are seen as a source of threat and instability.

The higher moral order, in the context of this study, is connected to timber legality. It is tied closely to notions of 'good' forest governance, that is purported as a key ingredient to combat the moral evils of deforestation and forest degradation (e.g. UN 2014). Those who fail to comply with the dominant understanding of how nature should be treated are criminalized (Brockington, Duffy and Igoe 2008; Colchester et al. 2006; Duffy 2010; Johnson 2019) and/or silenced in the international arena (Duffy 2013). While state actors consider acts against the rules to be malfeasance, many local communities see them as their customary right and as being intrinsically tied to notions of personhood and indigeneity (we elaborate on this later). Scott (1987) shows how local communities exercise subversion against the state by ignoring what they consider to be illegitimate law. Later, he claims that communities residing in regions distant from administrative power centers (in the hills) in Southeast Asia were not 'pushed' there but have deliberately chosen to live in historically inaccessible areas to avoid submitting to authorities and adhering to laws established by 'foreign' colonial and state powers (Scott 2009). Those who question the legitimacy of state-sanctioned initiatives aimed at addressing environmental issues risk being labelled as immoral or evil and equated with those who want to destroy forests.

\section{Theoretical synthesis}

Our theoretical framing considers the hegemony of Westphalian notions and practices of governance, which guide the globalization of governance, but result in legal pluralism because they are based on particular moralities that are not universal. Conceptualizations of the legal are rooted in 'global' moralities that are predisposed to understanding nature in a specific way. These understandings coexist with local ones in legal pluralities that often clash with hegemonic notions. What 'legal' entails is, therefore, a complex subject; however, we have set the foundation to explore through our empirical data the extent to which FLEGT, through the EUTR, and the VPAs perpetuate hegemonic notions and practices of legality and Westphalian notions of the nation-state. We will explore two crucial areas in the results section further below. First, we investigate whose legality these policies recognize that in order to understand the extent to which timber actors' voices are reflected or excluded in national and 'global' definitions of legality. We further explore the ways in which nonconformity with nation-state definitions of timber legality are understood by different actors, including the ways in which contrasting perspectives are framed by hegemonic powers. 


\section{Methods}

This article forms part of a larger study on understanding environmental justice issues in global timber production networks in the context of the EU's FLEGT Action Plan and Forest Stewardship Council (FSC) forest certification (see acknowledgements). Using semi-structured data collection instruments (the data collection instruments used are available at www.prodjus.eu), we interviewed over 500 actors from the village level, various levels of government, civil society, and industry in Ghana, Indonesia, Vietnam, and the EU. These countries were included in the research design to reflect different stages of VPA negotiations. Indonesia is a major exporter of wood furniture to the EU and was the most advanced in terms of implementation and initialized FLEGT licensing during fieldwork. Ghana, primarily a timber exporter, was the first to sign the VPA but was mired in technical difficulties that continued to impede the initialization of FLEGT licenses. Vietnam is a major exporter of wood furniture but also imports timber for production and announced its intent to sign the VPA during fieldwork. In this article, we focus on Indonesia, Ghana, and Europe; Vietnam has, however, been excluded since the effects of FLEGT had been less pronounced in the country at the time we conducted the fieldwork.

The interviews covered a range of themes, particularly ideas regarding the fairness and value of FLEGT EUTR and VPAs, perceptions on inclusion/exclusion in processes, and experiences with FLEGT EUTR and VPA implementation. The trading partner countries were selected based on their varying positions in relation to their VPAs at the time of selection in 2015. Within each country, we selected cases that represented salient issues and offered a diversity of experience. In Indonesia, for example, we followed timber and wood production in both plantations in Java and the natural forest in Kalimantan to their point of sale as primary processed and/or secondary processed wood products in domestic and international markets. In Ghana, timber exports predominantly consist of primary processed wood products and there is no significant export of furniture or other finished products; therefore, we focused on logging and sawmilling. We also asked each respondent for recommendations for further subjects to approach, which for industry actors was mostly trading partners and for policymakers and civil society were other actors of influence. To ensure gathering a comprehensive account, we interviewed actors from the forests of production countries to the retail shops in Europe and all types of actors in between.

Data were then coded according to our strategic data collection and coding framework using Dedoose (www.dedoose.com), a qualitative data analysis software package. We subsequently analyzed the data using primarily co-occurrence nodes. In this article, we use data from 29 interviews that specifically address the degree to which ideas and practices of legality are, or aren't, imposed. The notion of imposition was an inductive code that resulted from our data collection and was not something that we specifically sought out in the research. Our queries were more general in nature and pertained to governance structures and the effects of EU trade policies on production networks. Respondents remain anonymous in this article, referred to only with codes ascribed for this article and indicated by "\#". We have listed the general role of the respondents in the Annex to show the diversity of perspectives reflected in our results. Our findings are therefore not statistically representative but are indicative. We attempted to ensure the inclusion of multiple perspectives and be as encompassing as possible.

\section{Results}

The results below explore crucial areas in relation to understanding and interrogating the EU FLEGT as an expression of Westphalian ideas regarding governance and legality, and as an exercise of power. We initially ask, "whose legality?" in order to understand how different timber actors' voices are reflected or not in nation-state levels of timber legality definitions and at global levels. Second, we explore the ways in which non-conformity with nation-state definitions of timber legality are understood by different actors, including the ways in which contrasting perspectives are framed by hegemonic powers.

\section{Whose legality? The pluralities of written law and practice}

As mentioned previously, VPAs are framed by European actors as relegating the definitions of legality to trade partner countries. This positioning avoids repeating the missteps of past international development 
interventions that were viewed as top-down, overly prescriptive, and centrist (e.g. the Green Revolution, Structural Adjustment, and colonialism) (McMichael 2005; Bello, Cunningham and Rau 1994). As a European NGO (\#EU06) representative explained,

With the VPAs, it's a very important principle that it's not being imposed from outside, that what goes into those agreements is decided domestically and what's in domestic legislation. The EU has been very clever, to stand back is to say, 'what you need is a national consensus, but what you have in that agreement respects sovereignty, it's not for us to decide what's in your law, and in your VPA.' then adding, 'As long as it's meeting some minimum standards, so long as we see there is a national consensus behind it.'

Despite the EU's ostensible respect for the sovereign nation-states with whom it wishes to engage in legal trade, impressions of imposition and exclusion emerged in Ghana and Indonesia. These sentiments were found across a spectrum of civil society, industry, and the public sector and were expressed in relation to both the notion of legality and the process by which this notion was 'delivered' (i.e. how VPAs unfolded). A Ghanaian timber exporter explained, "In most of [the FLEGT] meetings, we see the whites participating and sharing their ideas as to how they want Ghanaians to manage their forest" (\#GH01). Another Ghanaian timber exporter concurred, "non-state actors did not have any influence in the formulation of the FLEGT process. FLEGT is an idea from Europe. We are only implementing what the white people wants [sic] us to do" (\#GH02). In Indonesia, a district forestry officer expressed the common sentiment that international consumers as well as development donors are dominant in determining national rules: "The rules of forest management, processing and trading are now greatly shaped by the international buyers, donor agencies supported by NGOs...buyers oblige producers to implement legality or chain of custody, and the government duly accepts it and implements the legality certification" (\#ID01).

The Indonesian legal system satisfying FLEGT requirements, the Sistem Verifikasi Legalitas Kayu/Timber Legality Verification System (SVLK), was influenced by the EU but is still described by at least some policymakers as "made in Indonesia" (\#ID02). These Indonesian state actors are proud of their independent timber verification system that policymakers insist is aligned with FLEGT but stands alone. However, respondents struggled to convincingly argue this. One key leader in the development of SVLK proclaimed, "I don't agree with views that SVLK manifestation in Indonesia is dictated by the EU. On the contrary, SVLK inspired the EU parliament to release the EUTR"; he later continued, "Indeed, we have to follow them and adjust our system in accordance to their regulation because the markets are in EU territory. We have to follow that" (\#ID03). Another key policymaker informant who was a part of the VPA negotiation delegation clarified, "In the VPA, the legality standard is defined by the respective countries so long as it is recognized by the EU as the partner" (\#ID04).

If FLEGT VPAs and European notions of legality are an imposition, they are perceived differently by different actors in producer countries, and those who stand to gain from international trade are observed to be the most tolerant. A small-scale exporter from Ghana suggested, "FLEGT will be fair to Europeans and the few law abiding big timber films that are interested in timber export. They are the only people that stand to gain from FLEGT. It will be business as usual for the rest of us" (\#GH03). The respondent positions the EU, the state and "law abiding big timber firms" against "the rest of us." The assumption that significant differences exist among timber actors in countries, both in relation to business traditions and practices, and in relation to the effects of VPAs is being demonstrated by emerging scholarship (see Maryudi and Myers 2018; Maryudi et al. 2020; Hansen, Rutt and Acheampong 2018 for more on winners and losers in FLEGT). Some respondents suggest that this gap between the EU, state, big firms, and "the rest of us" will lead to the demise of FLEGT. As a Ghanaian carpenter stated, the "VPA will not work in Ghana because the way we do our things are different from the way the whites conduct their business. They should keep their legality in Europe and allow us to continue with our business" (\#GH04). Irrespective of whether FLEGT succeeds or not in achieving its goals, the use of the phrase "keep their legality" indicates the perspective of differences and imposition. 
Customary users generally perceive global impositions on forestry practices as a reinforcement of preexisting nation-state impositions. Westphalian notions of statehood, reinforced by post-colonial notions of statehood, international arrangements, and now FLEGT, further legitimize the state's right to control natural resources. While some civil society projects aimed to address issues such as customary land tenure security, these initiatives were not directly connected with FLEGT. This omission is particularly striking in Ghana, where farmers effectively lack state-recognized rights to the native timber growing on their farms, and rely on the 'informal' extraction of timber based on customary law. Meanwhile, the state has continued to retain authority over on-farm timber, which they allocate via concessionaires to private companies (see Hirons et al. 2018). Reflecting on this situation, a local Ghanaian respondent suggested, "I think FLEGT should have considered the option of giving ownership of forest to fringe communities. FLEGT does not consider the needs of local communities" (\#GH05). Another village respondent in Ghana explained that communities are excluded from decisions relating to forest rules and that "policy makers do not believe in the knowledge of communities" (\#GH06). A customary leader in Indonesia expressed his opinions regarding "the tensions between perspectives on forest governance", stating that "this forest is public property, the villagers [should be] free to use this forest" (\#ID05). Another villager explained, "the rules that apply are customary rules. We don't regard the government rules; this often creates tensions between us and the government officials" (\#ID06). To many customary users, government officials are outsiders and are therefore not allowed entry into the forest without consent from the customary leaders according to customary law. It is, thus, the state that acts illegally (\#ID07) (see also Myers and Muhajir 2015 for how customary leaders placed customary sanction on the state for this reason). According to another community respondent in West Kalimantan, "changes must be made relating to forest management. We want indigenous forest in [our village] recognized by the central government, so that the management is in the village community" (\#ID08).

The FLEGT VPA could serve to either reinforce or break the cycle of the imposition of control over forests that affect the most forest-dependent the hardest. However, it recognizes the nation-state as the authority on legality. By not incorporating criteria on the inclusion of alternative approaches to legality, FLEGT supports approaches that ignore alternative perspectives. Even the imposition of participation in FLEGT processes has not yet led to meaningful re-conceptualizations of 'legality' to include, for example, customary law. As a European respondent (\#EU01) commented,

the challenge with the VPA process is that it's the Indonesian government that agrees with the EU about what the definition is. So if Indonesia does not have a law on indigenous peoples' rights to resources, EU cannot really go in and say, well you have to make those laws. Well, maybe they could, but that's not part of the VPA. The VPA takes its basis in the existing legal basis. I don't think they can go in and force a country to make new laws.

The description of the sovereignty of VPA partner countries in determining laws as a challenge suggests some of the cleavages between hegemonic legalities and alternative views.

In terms of whose legality is considered in the global and nation-state conceptualizations of legality and by extension the characterization of malfeasance, dissent among a range of actors in the timber and wood production networks can be observed. The basis of claim-making differs among these groups, but there is a shared sentiment among many that the hegemonic global/nation-state notions of legality are imposed upon them and that these notions contrast with their personal conceptualizations of legality.

\section{Framings of non-conformity: immorality and criminalization}

The previous section presented how varying actors in VPA partner countries view legality in different ways and practice different modes of doing business. However, for especially powerful actors including those at the EU level, legality evokes not merely law but also morality and 'goodness', about doing the 'right thing' and being a moral citizen. European industry actors described legality as the "right thing to do" (\#EU01 and 02, GH07), although they also referred to the reputational implications of dealing in illegal timber (\#EU03 and 04) - this is closely entangled with financial implications. In describing the difficulties of bringing the private 
sector meaningfully to the table (especially smaller actors), a European timber federation respondent commented that many of their constituents suspected that European development practitioners assumed that they were "evil" (\#EU05) (and that overcoming this evil was instrumental to progress).

Several European timber actors whom we interviewed stated that complying with legality requirements even outside their own areas of operation is an important part of demonstrating to their customers that they were dealing with legal products. Companies reported that dealing with illegal products is morally (i.e. public scrutiny) risky. Several industry respondents mentioned that civil society groups highlighting (proven or unproven) trading of illegal timber are a significant threat to their business. This risk was more often raised with larger companies and those who are direct operators (therefore, legally liable for legality verification). For smaller furniture importers, for example, respondents suggested that no customers have ever asked them about legality.

A Ghanaian timber exporter highlighted the link between legality and (at least the appearance of) morality. The respondent said,

morality influences the decision to trade in legal timber. For instance, the owner of [the company] is a Christian and also an environmentalist. He is therefore concerned with protecting the environment and leaving a good legacy in the timber industry. Greed, bureaucracies and unfairness in the issuance of permits forces certain timber firms and people to engage in illegal timber [trade]. (\#GH08)

This comment suggests that those engaging in illegal timber trade are morally corrupt, and or forced into corruption by corrupt officials, and those engaging in legal trade are virtuous and further ignores who decides what is legal and what is illegal. The concept of being 'forced' into illegal activities denotes that illegal actors are not inherently evil, but that they have no other alternatives. A village-level actor in Ghana reflected on forest laws as ineffective because "law enforcers and the chiefs lack the moral courage to arrest and prosecute offenders" (\#GH09).

Given the Westphalian and colonial foundations of forest governance in the countries under study, it is not surprising that hegemonic impositions of legality are either considered illogical or challenged at local levels. An Indonesian processor told us, "illegal timber is quite ambiguous because timber from community and private forest can be defined as illegal timber if they do not have [the accurate] legal document. On the other hand, timber from community forest have important roles on small-medium wood industries" (\#ID09). In Europe, actors acknowledge that many laws are unclear or illogical in the producing countries (see also Cầm et al. forthcoming). This is considered by some as hindering effective forest governance. An EU respondent said, "if you have a really bad country with no laws, then it's very easy to show that you are legal and you meet all laws" (\#EU01). This is, of course, a focus of FLEGT - to work with exporting countries to strengthen their laws.

It is not only customary land claimants who feel that their perspectives are not taken into account within domestic and foreign understandings of legality. We found examples of several other groups who felt demonized by the prescribed definitions of legality. Chief among these groups are the chainsaw millers (usually called illegal chainsaw millers) in Ghana. We located evidence of resentment resulting from such exclusion, thereby suggesting a lack of consideration of local realities in thinking about timber legality. Consistent with Hirons et al. (2018), chainsaw millers were found to be responsive to community needs and were able to work with communities in ways that maximized benefits to communities and minimized undesirable side effects of timber extraction that are often experienced by larger operators (\#GH10 and 11) (contrary to the rhetoric suggesting only large companies benefit communities, \#GH07). A timber processing company manager (\#GH07) explained, "I think global perceptions of fairness have influenced forest governance in Ghana significantly because the use of chainsaw machines for producing lumber was a common practice some years back but it has been abolished over the years." On the contrary, according to our interviews, 'illegal' chainsaw milling has been on the rise over the past few years. 
Chainsaw millers are far from abolished, but they have been criminalized and labelled as an enemy of responsible forestry (Acheampong and Marfo 2011; Acheampong and Marfo 2014; Hirons et al. 2018). These actors have been directly blamed for deforestation in the country.

The abolition of chainsaw milling is considered by many of the government and industry respondents as the key to ensuring the sustainability of the forest industry in Ghana, evident from the statements made by a representative of a large timber exporter regarding the cessation of illegal chainsaw millers as being the central objective of FLEGT (\#GH07). Another timber exporter stated, "If the youth get work to do, illegalities such as chainsaw lumbering will reduce. Most of the people engaging in chainsaw lumbering are the youth. They have no work to do so they always engage in illegal chainsaw lumbering" (\#GH13). In characterizing the chainsaw millers as jobless, the respondent's statement reveals the obscurity imposed on chainsaw operators by the hegemonic powers. The fact that chainsaw millers are a problem implies that they are gainfully employed but not in accordance with the state's preferences. Similarly, an Indonesia log harvester opined, "Stealing timber is a risky work. It is also viewed as 'bad work' in our community. I don't want my family to get involved. I do not want to either, but inadequate daily livelihood forces me to do so" (\#ID10).

Other small-scale actors also believe that the prevalent definitions of legal timber are unfair. In Indonesia, a small-scale logger said, "Once I got caught and jailed for 6 months when I did illegal logging. I think it was 15 years ago. It is a consequence as our activity is illegal. We are 'small people', we are powerless in the face of [the state forest company in Java] and the state" (\#ID10). Apart from illegal loggers, small businesses are also affected. A small producer mentioned that due to an increased focus on legal timber, "my business collapsed seven years ago. It used to be a glory for us in the timber business. Cheap timber, a lot of orders" (\#ID11). While global actors may have little sympathy for illegal loggers and those trading in illegally harvested timber, these livelihood activities were often observed to have been passed down from generations before the nation-state existed. If one further considers that under current legal frameworks the majority of timber consumed domestically in VPA countries such as Ghana and Indonesia, by both the urban and rural poor, is informal and, with the help of the VPA process, now formally defined as illegal, this suggests that the VPA is favoring European over developing country access to their own timber resources (see also McDermott, Hirons and Setyowati 2019).

In this section, we have identified some of the side effects of imposing notions of legality on specific groups of actors. Enforcement of certain global notions of legality produces new forms of malfeasance that may conflict with local notions and criminalize actors found to be in non-compliance with the hegemonic understandings of legality.

\section{Discussion}

Our results indicate that first, multiple notions exist regarding what makes timber harvesting and trading 'legal' and second, those who fail to conform with dominant notions and practices of legality are framed as immoral or criminal by powerful actors. In our discussion, we demonstrate how these findings comprise an expression of Westphalian hegemonic notions of legality and what that means for forest governance. We start with a discussion on impositions of legality, and then examine divergences to these impositions. Finally, we explore the hegemony of Westphalian notions of timber legality in the context of FLEGT.

\section{Impositions of legality}

In our theoretical introduction, we highlighted several ways in which the notions and practices of 'legality' can be understood differently or at least with more complexity than a singular notion of state-based law. We drew on theories of legal pluralism and alternative perspectives of the 'legal' or of codified morality. Our results highlight the complexity of the perceptions of legality in the context of FLEGT. We showed there were contrasting understandings of the extent to which the EU relies on definitions of legality by sovereign nation-states, thereby hinting at the notion that the concept of 'legality' has been imposed. We further demonstrated the contrasting legalities, specifically in terms of customary forest users and the state. We discuss each of these here briefly. 
Respondents often asserted that state-based legality is aligned with 'global' colonial approaches to legality, and positions European actors to benefit from increased attention to forest law and enforcement. The EU does not, and by international law would not be allowed to, impose VPAs on its partners. The EU also avoids the direct imposition of the definitions of legality on its partners. However, there exists a higher order of imposition that asserts that the national state actors engaged in VPA negotiations exclusively possess the right to define what is legal and what is not. Although reported most strongly among Ghanaian producer respondents, Indonesian producer respondents also believed that the EU-influenced requirements on legality were misaligned with the capacities of producers. This was, as expected, slightly different between larger and small producers in all countries; the former provided more support for state-authored legality definitions and monitoring while the latter claimed that the processes and requirements were too onerous. This issue is explored more in Maryudi et al. (2020).

We also demonstrated the contestations of customary users to further state intervention on forest management and control. Customary users stated clearly that legality imposed by the state is inconsistent with customary law. This may also ring true with hegemonic notions and practices of participation (see Cooke and Kothari 2001). The EU legitimation of the state in the understanding and verification of timber legality further entrenches this chasm by reinforcing that the state is the authority by which timber legality should be determined. However, this assumption has been found to be inapplicable in some cases. For example, the state's authority over forest land was successfully challenged by customary communities in the Constitutional Court in Indonesia (Myers et al. 2017). The assertion that the Westphalian nation-state understanding of legality is the only legitimate one, can be challenged by applying a similar logic.

We, therefore, claim that there are multiple understandings of legality, but the notion and practice of legality adopted by the EU and subsequently by the nation-states that sign VPAs is a hegemonic one that fails to consider contrasting definitions of legal timber. Actors who fail to comply with this hegemonic notion of timber legality are framed as deviants, unscrupulous, and criminal.

\section{Divergence from imposed legality}

Hegemonic notions of legality are embedded in the framings of morality. We show how behaviors presumed to be illegal by the state are considered differently by a range of actors. The hegemony of 'legality' is so strong that to challenge it is to commit an act of evil that allies one with plunderers of nature. A fear has therefore developed among subjects of the state regarding not only the legal and economic repercussions of the so-called malfeasance but also of being viewed by others as evil or irresponsible. This fear extends from local villagers to large companies. Several European companies commented that threats of fines or incarceration for contravening EUTR are far less than the ruining of their reputation by being accused of engaging in illegal timber trade or contributing to deforestation. Perhaps incarcerated traders would disagree with this contestation; their perspective could not be included, however, since no incarcerated traders were recorded in Europe at the time of writing. Villagers who are incarcerated, or subject to large fines, or who lose access to timber products altogether, might also suggest that their plight is worse than the sullied reputation of a company.

If trading legal timber is the 'right thing to do' then, by implication, trading illegal timber is 'wrong.' While this is taken at face value in Europe, the idea of 'legality' is subject to greater scrutiny in producing countries by actors living a plurality of legalities on a daily basis. The linchpin in this logic that legality equals morally right or 'good' is that legality is somehow benign if not benevolent. The parity of the concepts of legality and goodness is contested among customary land claimants whose forestlands are either inaccessible to them due to conservation boundaries or designated within the permissible activities for which concessionaires and developers have obtained permits; this is exemplified during the Suharto era of extreme unsustainable (though legal according to the state) logging in Indonesia (Casson and Obidzinski 2002). Furthermore, legal 'timber' is often buoyed by corrupt practices such as bribes and political patronage (J. Smith et al. 2003; Palmer 2001).

Some notions of legality - those aligned with the nation-state - are reinforced in global projects; however, contrasting perspectives, such as those by customary communities and poor actors, are weakened 
(Ribot, Chhatre and Lankinad 2008). Therefore, by choosing a specific course of action, global actors reinforce the legitimacy and authority of some actors and notions of legality. Furthermore, while the framing of nationstates as being instrumental to solutions may contribute to the authority and power of the 'Global South' VPA partner governments, it also creates an unusual opening for 'global' actors to intervene in the typically inaccessible rules and laws of sovereign states. This raises the question of whether this framing, advertently or not, promotes a particular notion of legality that poses real threats to those who seek alternative modes of governance.

\section{The hegemony of Westphalian notions of timber legality}

We now turn to a brief discussion of the theory that we raised earlier in this article regarding the Westphalian roots of this hegemonic notion of timber legality. We are not the first scholars to identify that forest regulations tend to criminalize less powerful groups (see also Obidzinski et al. 2014; McElwee 2004). Our argument is not limited to this identification but claims that the perspective from which these groups are demonized is rooted in hegemonic notions of forest governance and legality, including Westphalian notions of statehood. This implies that not only are some groups criminalized but there is also a generic one-size doesn't fit-all solution imposed on forests and forest actors that favors the centralization of efficient forest governance in the nation-state and contradicts or dismisses many local customs and land rights claims. In the process, contrary notions of legality and effective forest governance are relegated at best to community forestry on closely monitored state-sanctioned tracts of land within the confines of statutory law, and at worst dismissed as antithetical to environmental sustainability - and less overtly - to the authority of the state.

Forest governance projects often recentralize power by situating the nation-state in a central decisionmaking position (Basnyat et al. 2018; Sahide et al. 2016; Ribot, Agrawal and Larson 2006; Lund, Rutt and Ribot 2018). By placing the focus back on the state, the FLEGT, EUTR and VPAs effectively recentralize forest governance powers at the state level and move further away from the previous trend of ostensibly decentralized and market-driven governance structures (Montouroy 2013). Upon the implementation of the EUTR, market certification schemes are now no longer considered sufficient to demonstrate effective forest governance without further legality verification under the auspices of the state. FLEGT therefore has the effect of further entrenching the privatization and commodification of legality (Setyowati and McDermott 2016). The resistance to these global forest projects is, therefore, not surprising.

FLEGT at least obscures the relevance of non-state mechanisms for addressing unsustainable forest management, if not actually diminishing this relevance. However, is that a necessarily ineffective action? Some argue that the state is best positioned to protect and manage forests and natural resources. The same nationstates that determine what legal and illegal timber is, however, establish and enforce policies in other sectors that perpetuate deforestation and forest degradation; examples of such policies are agricultural and livestock conversion and urban expansion (Nepstad et al. 2009; Susanti and Maryudi 2016; Kissinger, Herold and De Sy 2012; DeFries et al. 2010). Cutler (2001) argues that Westphalian states are incapable of advancing the interests of non-state actors, the private industry, and informal structures; if FLEGT reinforces the Westphalian notions of statehood in such a situation, it could displace non-state solutions for improving forest governance (see also Cashore and Stone 2012; Putzel et al. 2015).

The EU's limited understanding and implementation of legality (van Heeswijk and Turnhout 2013) combined with its respect for sovereignty, comes at a cost to alternative notions and practices of legality. This is because the state's legality conflicts with other legalities, such as customary law or rights of nature and ignores all contestations of what is defined as legal by the state.

\section{Conclusions}

In this work, we explain how state-based legality in forest governance is hegemonic in two ways. First, it reinforces the state's authority to determine the forms of governance that are legitimate. Second, understandings of legality in nation-states often stem from Eurocentric forest management principles, based on the establishment of concessions for export, that have been either inherited through colonial policies or incorporated into domestic policies through international societies. We suggest that the EU FLEGT perpetuates 
these hegemonic understandings of legality, and associated privileging of global over local access to timber, thereby strengthening the authority of nation-states to implement 'international' understandings of forest governance and legality. The EU FLEGT VPAs, for example, are enabled by the EU; thus, they are representative of particular values of EU Member State development agencies and European NGOs and IGOs mobilized by European Commission funding. These values are consistent with the world capitalist economy and imposed through markets. There is, therefore, a scaled political ecology of FLEGT.

We also, from personal perspectives, believe that participation of a wider range of stakeholders in forest governance by better engaging smallholders, small-scale operators, and customary communities is a step in the right direction. However, the cost of imposing these notions and practices of governance and legality is significant. Not only are the actors who refuse to conform with state laws framed as deviants and criminals, there is also a fear especially among smaller-scale producers, whose access is largely precluded by existing legal structures, of an outright loss of their livelihood. As our study shows, the FLEGT proponents' assumptions on the role and universality of centralized state control over natural resources are contested amongst many actors.

The highly diverse local practices, which provide the majority of timber to the urban and rural poor in VPA countries such as Indonesia and Ghana, are trivialized with terms such as 'informal' and 'traditional', and attributed the same notions of criminality. In practice, many of the 'illegal' timber extractions align with (locally legitimate) customary law that may be more contextually relevant to sustainability. Alternative forest governance practices to those prescribed by the state are in effect weakened by the legitimization of the nationstate notions of legality. This could have the effect of further muting the voices of those who are already underrepresented in decisions about forests and trees over which they have a claim and that they call home.

Fraser (2009) calls for a post-Westphalian framing of problems in a globalizing world to ensure that rather than imagined states claiming to address social issues, an 'all-affected' principle should be applied in which "those affected by a given social structure or institution have moral standing as subjects of justice" (p. 24). Fraser (2005a: 82) explains in an earlier work, "Until recently, the all-affected principle seemed to coincide in the eyes of many with the state-territorial principle [...] Today, however, the idea that state-territoriality can serve as a proxy for social effectivity is no longer plausible." The EU FLEGT, including its VPAs and EUTR, is a project embodying the logic of state supremacy through the frame of illegality as the problem, with laws and regulations as the solution. It simultaneously emphasizes anti-hegemonic (or different kinds of hegemonic) notions such as public participation in decision-making. Meanwhile, the framing of the problem as being global represents an opening that may contrast with the sovereignty principle of Westphalia. As the EU claims the power to implement the agenda and the solution within foreign sovereign states, it legitimizes the Westphalian state as the agent of globalized hegemonic notions of the legal and illegal. Non-state-based solutions such as private timber certification carry their characteristic constraints and challenges but at least have the potential to foster alternative visions of 'good' and 'bad' forest governance. The observations from our analysis of the logics of hegemonic notions of governance and legality applied to the world's forests are consistent with Fraser's (2005b) analysis that people most subjugated to globalization are excluded from decision-making or even the framing of the problem. The core concern that should be studied further and more extensively in subsequent research and policy work is the troubling nature of these framings of effective forest governance and legality, and the EU's role in perpetuating these (problematic) hegemonic logics.

\section{References}

Abrams, J., E. Nielsen, D. Diaz, T. Selfa, E. Adams, J.L. Dunn and C. Moseley. 2018. How do states benefit from nonstate governance? Evidence from forest sustainability certification. Global Environmental Politics 18:3: 66-85.

Acheampong, E. and E. Marfo. 2011. The impact of tree tenure and access on chainsaw milling in Ghana. Ghana Journal of Forestry 27: 68-86.

Acheampong, E. and E. Marfo. 2014. Chainsaw operators, alternative livelihood options and climate change mitigation. Kumasi: CSIR Forestry Research Institute of Ghana. 
Arora-Jonsson, S., L. Westholm, B.J. Temu and A. Petitt. 2016. Carbon and cash in climate assemblages: the making of a new global citizenship. Antipode 48(1): 74-96.

Basnyat, B., T. Treue, R.K. Pokharel, L.N. Lamsal and S. Rayamajhi. 2018. Legal-sounding bureaucratic recentralisation of community forestry in Nepal. Forest Policy and Economics 91: 5-18.

Becker, L.C. 2001. Seeing green in Mali's woods: colonial legacy, forest use, and local control. Annals of the Association of American Geographers. Association of American Geographers 91(3): 504-526.

Bello, W.F., S. Cunningham and B. Rau. 1994. Dark victory: the United States, structural adjustment, and global poverty. London: Pluto.

von Benda-Beckmann, F., K. von Benda-Beckmann and A. Griffiths. 2012. The power of law. In F. von BendaBeckmann, K. von Benda-Beckmann and A. Griffiths (eds.). The power of law in a transnational world: anthropological enquiries. New York: Berghahn Books. Pp. 1-32.

von Benda-Beckmann, K. 2002. Globalization and legal pluralism. International Law Forum 4(1): 19-25.

Bernstein, S. and B. Cashore. 2012. Complex global governance and domestic policies: four pathways of influence. International Affairs 88(3): 585-604.

Black, H.C. 1990. Black's law dictionary. 6th ed. St. Paul, MN: West Publishing Co.

Brockington, D., R. Duffy and J. Igoe. 2008. Nature unbound: conservation, capitalism and the future of protected areas. London: Earthscan.

Bull, H. 1977. The anarchical society: a study of order in world politics. New York: Palgrave Macmillan.

Bull, H. and A. Watson. 1984. The expansion of international society. Oxford: Clarendon Press.

Câm, H., C. McDermott and R. Myers. forthcoming. From global justice to local [in]justice: timber market mechanisms, legality and politics of justice in Vietnam. Journal of Vietnamese Cultural Studies 2.

Caporaso, J.A. 1996. The European Union and forms of state: Westphalian, regulatory or post-modern? JCMS: Journal of Common Market Studies 34(1): 29-52.

Cashore, B., G. Auld and D. Newsom. 2004. Governing through markets: forest certification and the emergence of non-state authority. New Haven: Yale University Press.

Cashore, B., S. Leipold, P.O. Cerutti, G. Bueno, S. Carodenuto, X. Chen, W. de Jong, A. Denvir, C. Hansen, D. Humphreys, K. McGinley, I. Nathan, C. Overdevest, R.J. Rodrigues, M. Sotirov, M.W. Stone, Y. T. Tegegne, I. Visseren-Hamakers, G. Winkel, V. Yemelin and J. Zeitlin. 2016. Global governance approaches to addressing illegal logging: uptake and lessons learnt. In D. Kleinschmit, S. Mansourian, C. Wildburger and A. Purret (eds.). Illegal logging and related timber trade-dimensions, drivers, impacts and responses. a global scientific rapid response assessment report. IUFRO. Pp.119-132.

Cashore, B. and M.W. Stone. 2012. Can legality verification rescue global forest governance? Analyzing the potential of public and private policy intersection to ameliorate forest challenges in Southeast Asia. Forest Policy and Economics 18 (May): 13-22.

Casson, A. and K. Obidzinski. 2002. From new order to regional autonomy: shifting dynamics of" illegal" logging in Kalimantan, Indonesia. World Development 30: 2133-2151.

Chomba, S., J. Kariuki, J.F. Lund and F. Sinclair. 2016. Roots of inequity: how the implementation of REDD+ reinforces past injustices. Land Use Policy 50: 202-213.

Claire Cutler, A. 2001. Critical reflections on the Westphalian assumptions of international law and organization: a crisis of legitimacy. Kokusaigaku Revyu = Obirin Review of International Studises 27(2): 133-150.

Colchester, M., M. Boscolo, A. Contreras-Hermosilla, F. Del Gatto, J. Dempsey, G. Lescuyer, K. Obidzinski, D. Pommier, M. Richards, S.N. Sembiring, L. Tacconi, M.T.V. Rios and A. Wells. 2006. Justice in the forest: rural livelihoods and forest law enforcement Vol. 3. Forest Perspectives. Bogor: CIFOR.

Commission of European Communities. 2003. Forest Law Enforcement, Governance and Trade (FLEGT): Proposal for an EU Action Plan: Communication from the Commission to the Council and the 
European Parliament. COM (Commission of the European Communities). Office for Official Publications of the European Communities.

Cooke, B. and U. Kothari. 2001. Participation: the new tyranny? London: Zed.

David, R. and J.E.C. Brierley. 1978. Major legal systems in the world today: an introduction to the comparative study of law. New York: Simon and Schuster.

Dawson, N., B. Coolsaet and A. Martin. 2018. Justice and equity: emerging research and policy approaches to address ecosystem service trade-offs. In K. Schreckenberg, G. Mace and M. Poudyal (eds.). Ecosystem services and poverty alleviation. London: Routledge. Pp. 22-38.

DeFries, R.S., T. Rudel, M. Uriarte and M. Hansen. 2010. Deforestation driven by urban population growth and agricultural trade in the Twenty-First century. Nature Geoscience 3 (February 7): 178.

Diaw, M.C. 2005. Modern economic theory and the challenge of embedded tenure institutions: African attempts to reform local forest policies. In S. Kant and R.A. Berry (eds.). Institutions, sustainability, and natural resources. Dordrecht: Springer. Pp. 43-81.

Dingwerth, K. 2008. Private transnational governance and the developing world: a comparative perspective. International Studies Quarterly 52: 607-634.

Djelic, M.-L. and K. Sahlin-Andersson. 2006. Introduction: a world of governance: the rise of transnational regulation. In M.-L. Djelic and K. Sahlin-Andersson (eds.). Transnational governance: institutional dynamics of regulation. Cambridge: Cambridge University Press. Pp. 1-30.

Duffy, R. 2010. Nature crime: how we're getting conservation wrong. New Haven: Yale University Press.

Duffy, R. 2013. Global environmental governance and North-South dynamics: the case of the CITES. Environment and Planning. C: Government and Policy 31(2): 222-239.

Eagleton, T. 1991. Ideology: an introduction. London: Verso.

EU FLEGT Facility. 2009. What is a Voluntary Partnership Agreement? - the European Union approach. Policy Brief 3.

EU FLEGT Facility. 2019. Where we work. EU FLEGT Facility. http://www.euflegt.efi.int/where-we-work

European Parliament and Council. 2010. EC 995/2010.

European Parliament and Council. 2010. EC 995/2010.

Federer, W.J. 2004. Treasury of Presidential quotations. St. Louis: Amerisearch.

Fraser, N. 2005a. Reframing justice in a globalizing world. New Left Review 36: November-December.: 6988.

Fraser, N. 2005b. Reframing justice. Amsterdam: Koninklijke van Gorcum.

Fraser, N. 2009. Scales of justice: reimagining political space in a globalizing world. New York: Columbia University Press.

Grove, R.H. 1996. Green imperialism: colonial expansion, tropical island edens and the origins of environmentalism, 1600-1860. Cambridge: Cambridge University Press.

Hansen, C.P. and J.F. Lund. 2017. Imagined forestry: the history of the scientific management of Ghana's High Forest Zone. Environment and History 23(1): 3-38.

Hansen, C.P., R. Rutt and E. Acheampong. 2018. 'Experimental' or business as usual? implementing the European Union Forest Law Enforcement, Governance and Trade (FLEGT) Voluntary Partnership Agreement in Ghana. Forest Policy and Economics 96: 75-82.

van Heeswijk, L. and E. Turnhout. 2013. The discursive structure of FLEGT (Forest Law Enforcement, Governance and Trade): the negotiation and interpretation of legality in the EU and Indonesia. Forest Policy and Economics 32: 6-13.

Hirons, M., C. McDermott, R. Asare, A. Morel, E. Robinson, J. Mason, E. Biyd, Y. Malhi and K. Norris. 2018. Illegality and inequity in Ghana's cocoa-forest landscape: the role of formalization. Land Use Policy 76: 405-413. 
Humphreys, D. 2004. Redefining the issues: NGO influence on international forest negotiations. Global Environmental Politics 4(2): 51-74.

Humphreys, D. 2006. Logjam: deforestation and the crisis of global governance. London: Earthscan.

Hurrell, A. 2002. Foreword to the Third Edition. In H. Bull (ed.). The anarchical society: a study of order in world politics. New York: Palgrave Macmillan. Pp. vii-xxiii.

Interpol. 2017. Project Leaf: global forestry assessment. Interpol. https://www.leaf.global/

Johnson, M.F. 2019. Who governs here? informal resource extraction, state enforcement, and conflict in Ghana. Global Environmental Change 58: 101959. Advance online publication.

Keene, E. 2002. Beyond the anarchical society: Grotius, colonialism and order in world politics. Cambridge: Cambridge University Press.

Keohane, R.O. 1984. After hegemony: cooperation and discord in the world political economy. Princeton: Princeton University Press.

Kissinger, G.M., M. Herold and V. De Sy. 2012. Drivers of deforestation and forest degradation: a synthesis report for REDD+ policymakers. Lexeme Consulting.

Krasner, S.D. 1999. Globalization and sovereignty. In D.A. Smith, D.J. Solinger and S.C. Topik (eds.). States and sovereignty in the global economy. London: Routledge. Pp. 34-52.

Krasner, S.D. 2001. Rethinking the sovereign state model. Kokusaigaku Revyu = Obirin Review of International Studies 27(5): 17-42.

Lescuyer, G., P.O. Cerutti and V. Robiglio. 2013. Artisanal chainsaw milling to support decentralized management of timber in Central Africa? An analysis through the theory of access. Forest Policy and Economics 32: 68-77.

Lesniewska, F. and C.L. McDermott. 2014. FLEGT VPAs: laying a pathway to sustainability via legality lessons from Ghana and Indonesia. Forest Policy and Economics 48: 16-23.

Lund, J.F., R.L. Rutt and J. Ribot. 2018. Trends in research on forestry decentralization policies. Current Opinion in Environmental Sustainability 32: 17-22.

Marfo, E. 2009. Chainsaw milling in Ghana: an overview of the issues. Kumasi: Tropenbos International and CSIR Forestry Research Institute of Ghana.

Marks, G. 1992. Structural policy in the European Community. In A. Sbragia (ed.). Euro-politics: institutions and policymaking in the "new" European Community. Washington, DC: Brookings Institution Press. Pp. 191-224.

Maryudi, A. 2015. Rejim politik kehutanan internasional. Yogyakarta: UGM Press.

Maryudi, A., E. Acheampong, R. Rutt, R. Myers and C. McDermott. 2020. "A level playing field"? - what an environmental justice lens can tell us about who gets leveled in the Forest Law Enforcement, Governance and Trade Action Plan. Society and Natural Resources 3(1): 1-17.

Maryudi, A. and R. Myers. 2018. Renting legality: how FLEGT is reinforcing power relations in Indonesian furniture production networks. Geoforum 97: 46-53.

Maryudi, A. and M.A.K. Sahide. 2017. Research trend: power analyses in polycentric and multi-level forest governance. Forest Policy and Economics 81: 65-68.

Masiero, M., D. Pettenella and P. Cerutti. 2015. Legality constraints: the emergence of a dual market for tropical timber products? Forests 6(10): 3452-3482.

McDermott, C.L. 2014. REDDuced: From sustainability to legality to units of carbon-the search for common interests in international forest governance. Environmental Science and Policy 35: 12-19.

McDermott, C.L., M. Hirons and A. Setyowati. 2019. The interplay of global governance with domestic and local access: insights from the FLEGT VPAs in Ghana and Indonesia. Society and Natural Resources 33(2): 261-279.

McElwee, P. 2004. You say illegal, I say legal: the relationship between 'illegal' logging and land tenure, poverty and forest use rights in Vietnam. Journal of Sustainable Forestry 19(1/2/3): 97-135.

McMichael, P. 2005. Global development and the corporate food regime. In Buttel, F. H. and P. McMichael (eds.). New directions in the sociology of global development. Bingley: Emerald. Pp. 265-299. 
Milanovic, B. 2003. The two faces of globalization: against globalization as we know it. World Development 31(40): 667-683.

Montouroy, Y. 2013. The EU FLEGT Action Plan to Counter Illegal Logging: recentralization of European rule making, international cooperation and privatized global forest governance. 1rst ICPP 2013. ICPP. Grenoble: 26-28 June 2013.

Mwangi, E. and A. Wardell. 2012. Multi-level governance of forest resources. International Journal of the Commons 6(2).

Myers, R., D. Intarini, M. Sirait and A. Maryudi. 2017. Claiming the forest: inclusions and exclusions under Indonesia's 'new' forest policies on customary forests. Land Use Policy 66: 205-213.

Myers, R. and M. Muhajir. 2015. Searching for justice: rights vs 'benefits' in Bukit Baka Bukit Raya National Park, Indonesia. Conservation and Society 13(4): 370-381.

Nader, L. 2009. Law and the frontiers of illegalities. In von Benda- Beckman F., K. von Benda-Beckman and A. Griffiths (eds.). The power of law in a transnational world. New York: Berghahn Books. Pp. 54-73.

Nepstad, D., B.S. Soares-Filho, F. Merry, A. Lima., P. Moutinho, J. Carter, M, Bowman, A. Cattaneo, H. Rodrigues, S. Schwartzman, D.G. McGrath, C.M. Stickler, R. Lubowski., P. Piris-Cabezas, S. Rivero, A. Alencar, O. Almeida and O. Stella. 2009. The end of deforestation in the Brazilian amazon. Science 326(5958): 1350-1351.

Neumann, R.P. 1997. Forest rights, privileges and prohibitions: contextualising state forestry policy in colonial Tanganyika. Environment and History 3(1): 45-68.

Obidzinski, K., A. Dermawan, A. Andrianto, H. Komarudin and D. Hernawan. 2014. The Timber Legality Verification System and the Voluntary Partnership Agreement (VPA) in Indonesia: challenges for the small-scale forestry sector. Forest Policy and Economics 48: 24-32.

Okereke, C. 2008. Global justice and neoliberal environmental governance: ethics, sustainable development and international co-operation. London: Routledge.

Overbeek, H., K. Dingwerth, P. Pattberg and D. Compagnon. 2010. Forum: global governance: decline or maturation of an academic concept? International Studies Review 12(4): 696-719.

Overdevest, C. and J. Zeitlin. 2018. Experimentalism in transnational forest governance: implementing European Union Forest Law Enforcement, Governance and Trade (FLEGT) Voluntary Partnership Agreements in Indonesia and Ghana. Regulation and Governance 12: 64-87.

Palmer, C. 2001. The extent and causes of illegal logging: an analysis of a major cause of tropical deforestation in Indonesia. London/Norwich: Centre for Social and Economic Research on the Global Environment (CSERGE).

Peluso, N.L. 1992. Rich forests, poor people: resource control and resistance in Java. Berkeley: University of California Press.

Putzel, L., A.B. Kelly, P.O. Cerutti and Y. Artati. 2015. Formalization as development in land and natural resource policy. Society and Natural Resources 28(5): 453-472.

Quijano, A. 2000. Coloniality of power and Eurocentrism in Latin America. International Sociology: Journal of the International Sociological Association 15(2): 215-232.

Rajagopal, B. 2003. International law from below: development, social movements and Third World resistance. Cambridge: Cambridge University Press.

Randeria, S. 2003. Cunning states and unaccountable international institutions: legal plurality, social movements and rights of local communities to common property resources. European Journal of Sociology/Archives Europeennes de Sociologie 44(1): 27-60.

Ribot, J. 1999. Decentralization, participation and accountability in Sahelian forestry: legal instruments of political-administrative control. Africa 69(1): 23-65.

Ribot, J., A. Agrawal and A.M. Larson. 2006. Recentralizing while decentralizing: how national governments reappropriate forest resources. World Development 34: 1864-1886.

Ribot, J., A. Chhatre and T. Lankinad. 2008. Introduction: institutional choice and recognition in the formation and consolidation of local democracy. Conservation and Society 6(1): 1-11. 
Rutt, R., R. Myers, C.L. McDermott and S. Ramcilovik-Suominen. 2018. FLEGT: Another forestry fad? Environmental Science and Policy 89: 266-272.

Sahide, M.A.K., A. Maryudi, S. Supratman and L. Giessen. 2016. Is Indonesia utilising its international partners? The driving forces behind Forest Management Units. Forest Policy and Economics 69: 1120.

Scott, J.C. 1987. Weapons of the weak: everyday forms of peasant resistance. New Haven: Yale University Press.

Scott, J.C. 2009. The art of not being governed: an anarchist history of upland Southeast Asia. New Haven: Yale University Press.

Setyowati, A. and C.L. McDermott. 2016. Commodifying legality? Who and what counts as legal in the Indonesian wood trade. Society and Natural Resources 30(6): 750-764.

Shapiro, S.J. 2011. Legality. Cambridge, MA: Harvard University Press.

Sikor, T. and C. Lund. 2009. Access and property: a question of power and authority. Development and Change 40(1): 1-22.

Slaughter, A.M. and W. Burke-White. 2006. The future of international law is domestic (or, the European Way of law). Harvard International Law Journal 47(2): 327-352.

Smith, J., K. Obidzinski, S. Subarudi and I. Suramenggala. 2003. Illegal logging, collusive corruption and fragmented governments in Kalimantan, Indonesia. International Forestry Review 5(3): 293-302.

Susanti, A. and A. Maryudi. 2016. Development narratives, notions of forest crisis, and boom of oil palm plantations in Indonesia. Forest Policy and Economics 73: 130-139.

UN. 2014. New York Declaration on Forests: declaration and action agenda. New York: Climate Summit 2014.

Vandergeest, P. and N.L. Peluso. 2006. Empires of forestry: professional forestry and state power in Southeast Asia, Part 2. Environment and History 12: 359-393.

Vogel, D. 1995. Trading up: consumer and environmental regulation in a global economy. Cambridge, MA: Harvard University Press.

Wainwright, J.D. and C.L. Zempel. 2017. The colonial roots of forest extraction: rosewood exploitation in Southern Belize. Development and Change 49(1): 1-26.

Watson, A. 1992. The evolution of international society: a comparative, historical analysis. London: Routledge.

Weilenmann, M. 2009. Project law_a legal intermediary between local and global communities: a case study from Senegal. Anthropologica 51(1): 39-51.

Weimar, H., N. Janzen and M. Dieter. 2015. Market coverage of wood imports by the EU Timber Regulation. Thünen Working Paper 45. Hamburg: Johann Heinrich von Thünen-Institut. 
Annex: Summary of Respondents

\begin{tabular}{|c|c|c|}
\hline Ref Number & Region & Sector/ Level \\
\hline EU01 & European Union & Civil society \\
\hline EU02 & European Union & Industry \\
\hline EU03 & European Union & Industry \\
\hline EU04 & European Union & Industry \\
\hline EU05 & European Union & Industry \\
\hline EU06 & European Union & Civil society \\
\hline GH01 & Ghana & Industry \\
\hline GH02 & Ghana & Industry \\
\hline GH03 & Ghana & Industry \\
\hline $\mathrm{GH} 04$ & Ghana & Industry \\
\hline GH05 & Ghana & Industry \\
\hline GH06 & Ghana & Village \\
\hline GH07 & Ghana & Industry \\
\hline GH08 & Ghana & Industry \\
\hline GH09 & Ghana & Village \\
\hline GH10 & Ghana & Village \\
\hline GH11 & Ghana & Civil society \\
\hline GH12 & Ghana & Industry \\
\hline GH13 & Ghana & Industry \\
\hline ID01 & Indonesia & Government \\
\hline ID02 & Indonesia & Civil society \\
\hline ID03 & Indonesia & Industry \\
\hline ID04 & Indonesia & Research \\
\hline ID05 & Indonesia & Village \\
\hline ID06 & Indonesia & Village \\
\hline ID07 & Indonesia & Village \\
\hline ID08 & Indonesia & Village \\
\hline ID09 & Indonesia & Industry \\
\hline ID10 & Indonesia & Village \\
\hline ID11 & Indonesia & Village \\
\hline
\end{tabular}

